\title{
THE EFFECT OF PROGESTERONE IMPLANTS ON OVULATION AND PLASMA LEVELS OF LH, FSH AND PROGESTERONE IN ANOESTROUS EWES
}

\author{
N. SABA, N. F. GUNNINGHAM, A. M. SYMONS* \\ AND P. G. MILLAR \\ Ministry of Agriculture, Fisheries and Food, Central Veterinary Laboratory, \\ Weybridge, Surrey $K \mathcal{T} 153 \mathcal{N} B$
}

(Received 30th October 1974)

\begin{abstract}
Summary. The effects of 100-mg progesterone implants in anoestrous ewes on plasma progesterone and gonadotrophin levels are described. Implant removal resulted in a surge of plasma gonadotrophins and ovulation, but there was no evidence of behavioural oestrus in $90 \%$ of the ewes. These results are discussed.
\end{abstract}

\section{INTRODUCTION}

Various procedures have been used to synchronize oestrus in cyclic ewes and to induce ovulation and oestrus in anoestrous ewes. Dziuk \& Cook (1966) found that implants of melengestrol acetate sealed in silicone rubber tubes reduced the incidence of heat in cyclic ewes, and that there appeared to be some synchronization of oestrus when the implants were removed. Falkenburg, Hulet \& Kaltenbach (1971) studied the effects of solid silicone rubber implants impregnated with progesterone combined with other hormonal treatments on synchronization of oestrus and conception rates in cyclic ewes, and Mauer, Revenal, Johnson, Moyer, Hirata \& White (1972) investigated the effects of similar progesterone-silicone implants on plasma LH levels and oestrus in cyclic and non-cyclic ewes. These studies showed that, after implant removal, there was a considerable degree of oestrus synchronization and Mauer et al. (1972) observed a difference between cyclic and non-cyclic ewes in the timing of the plasma LH surge. In the present study we describe some of the effects of progesterone-silicone rubber tube implants on the plasma levels of progesterone, $\mathrm{LH}$ and FSH and on ovulation in anoestrous ewes. A preliminary report on the changes in plasma progesterone during the period of implantation has been published (Symons, Cunningham, Saba \& Millar, 1974).

\section{MATERIALS AND METHODS}

Radioimmunoassay of FSH and $L H$. Plasma FSH was determined by the method of Cunningham \& Hebert (1973), and plasma LH as described by Symons, Cunningham \& Saba (1974).

* Present address: Department of Biochemistry, University of Surrey, Guildford, Surrey. 
Progesterone was determined by a radioimmunoassay as previously described (Symons, 1973).

Progesterone implants. These were prepared according to the procedure of Dziuk \& Cook (1966), and consisted of 9-cm lengths of Silastic tubing (i.d. $3.18 \mathrm{~mm}$, o.d. $6.35 \mathrm{~mm}$ ) containing $100 \mathrm{mg}$ progesterone and were sealed at both ends. They were sterilized by heating for $20 \mathrm{~min}$ at $5 \mathrm{lbf} / \mathrm{in}^{2}\left(109^{\circ} \mathrm{C}\right)$ and then implanted into ewes as described previously (Symons, Cunningham Saba \& Millar, 1974).

Experimental animals. Twenty anoestrous crossbred Suffolk ewes, 4 to 5 years old, which had lambed during March and April were brought into the indoor experimental pens about 7 days before the start of the experiment in July. No artificial light schedule was used. On Day -10 of the experiment, all ewes received one progesterone implant and an intramuscular injection of $500 \mu \mathrm{g}$ oestradiol suspended in $2 \mathrm{ml}$ of $0.9 \% \mathrm{NaCl}$. On Day 0 , the day of removal of the implants, the ewes were allocated to four groups (each consisting of five ewes) which received the following treatments. Group 1 : implants were removed at 17.00 hours and $48 \mathrm{hr}$ later (Day 2), each ewe was injected intramuscularly with $2 \mathrm{ml}$ saline; Group 2: treatment was similar to that for Group 1, except that each ewe was injected with $50 \mu \mathrm{g}$ oestradiol in $2 \mathrm{ml}$ saline on Day 2; Group 3: implants were removed at 05.00 hours and, $48 \mathrm{hr}$ later (Day 2), each ewe was injected with $2 \mathrm{ml}$ saline; Group 4 : treatment was similar to that for Group 3, except that each ewe was injected with $50 \mu \mathrm{g}$ oestradiol in $2 \mathrm{ml}$ saline on Day 2.

Groups 1 and 2, and Groups 3 and 4 were penned separately. After removal of the progesterone implant, the oestrous condition was determined by vulval examination and the behaviour of the ewe towards the ram. Observations on vulval appearance were made during the period 3 to 6 days after removal of the implant, and changes in appearance were classified into three stages. Stage 1anoestrus. The vulva appeared wrinkled and the vestibular mucous membrane exposed by digital parting of the lips was pale and its surface dry. Stage 2beyond anoestrus but not at full oestrus. The vulval lips were swollen, obliterating the fine wrinkles although deep folds were still evident. The vestibular mucous membrane, seen only after the lips had been retracted, was only slightly hyperaemic and dry. Stage 3-full oestrus. The vulval lips were swollen and tumescent, with no evidence of wrinkling, and the mucous membrane glistening and moistened by a clear thin genital mucoid secretion, was visible without digital manipulation. Stage 1 was easily distinguished from Stages 2 and 3, but there was no clear distinction between Stages 2 and 3. Stages 1,2 and 3 were scored as $0, \frac{1}{2}$ and 1 respectively.

Behavioural oestrus was detected by introducing a ram of known fertility into each pen for $30 \mathrm{~min}$ every $6 \mathrm{hr}$ during the period 24 to $48 \mathrm{hr}$ after removal of the implant and every $3 \mathrm{hr}$ during the following $48 \mathrm{hr}$. From Day 4 to Day 8 after implant removal, oestrous behaviour was tested once daily at 14.00 hours. Ewes were judged to be in oestrus if they accepted the ram and stood firmly when mounted.

All the animals were killed 14 days after implant removal and the ovaries were examined for corpora lutea and enlarged follicles. 
Control ewes. Five untreated ewes, similar to the experimental animals in breed, age and lambing history, were killed at the same time as the experimental sheep and their ovaries were examined.

Blood sampling. Blood samples were collected from the jugular vein into heparinized tubes, and the plasma stored at $-20^{\circ} \mathrm{C}$ until required for hormone assay. Samples were taken from the experimental ewes only on the day before (Day -11 ) and $1,3,6$ and 10 days after (Days $-9,-7,-4$ and 0 , respectively) implant insertion. After implant removal, blood samples were taken every $6 \mathrm{hr}$ during the first $48 \mathrm{hr}$, every $3 \mathrm{hr}$ during the next $48 \mathrm{hr}$ and on Days $6 \frac{1}{2}$ to 7 , $7 \frac{1}{2}$ to $8,8 \frac{1}{2}$ to $9,10 \frac{1}{2}$ to 11 and $13 \frac{1}{2}$ to 14 .

\section{RESULTS}

\section{Ewe 671 (Group 3)}

The plasma progesterone concentrations in this ewe after implant removal were so anomalous that the results have not been included in the data for Group 3. Although the ewe's plasma progesterone concentrations were similar to those of the other animals before implantation, during implantation and $6 \mathrm{hr}$ after implant removal, the results for samples taken on Days 1, 2 and 3 were abnormally high (see Text-fig. 1). It seems unlikely that this was due to excess leakage of progesterone from the implant at the time of removal, as the im-

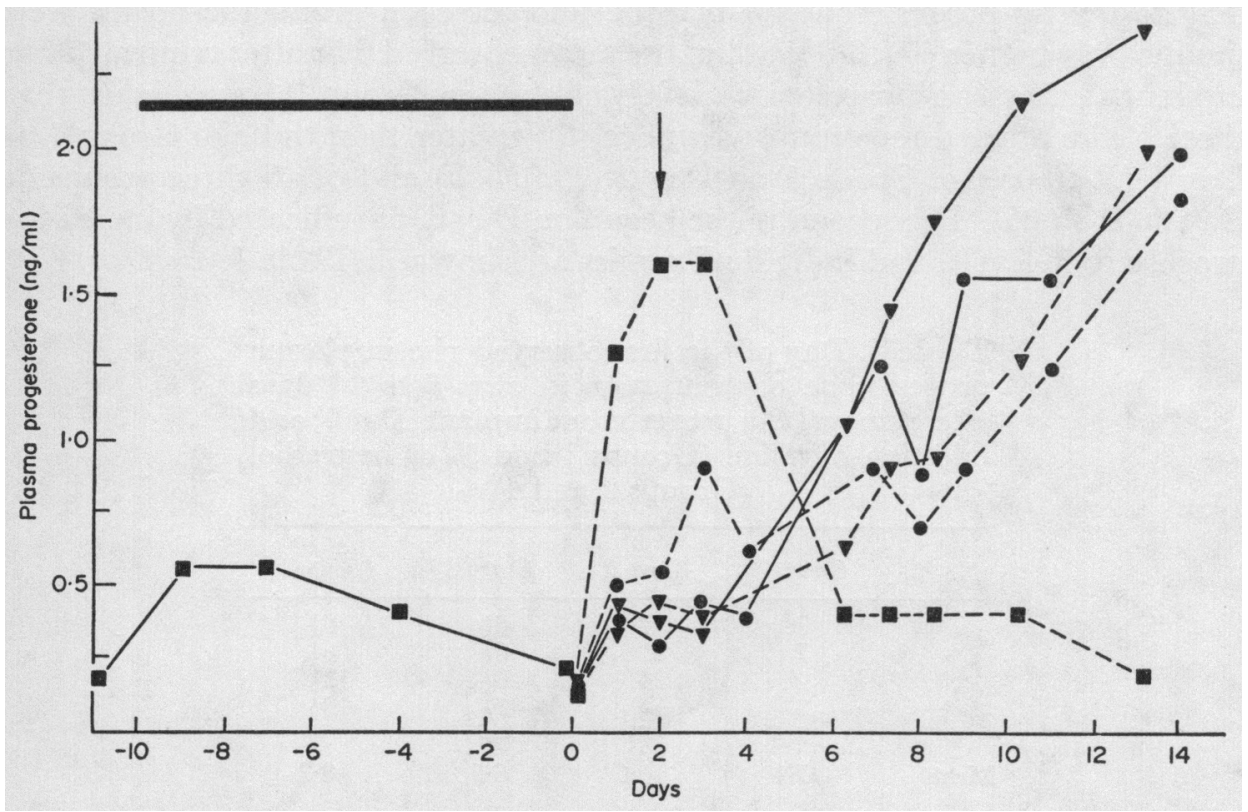

Text-Fig. 1. Plasma progesterone concentrations in anoestrous ewes with an implant of progesterone (horizontal bar) and after removal of the implant on Day 0. All animals were injected with $500 \mu \mathrm{g}$ oestradiol at the time of implant insertion. The arrow indicates the time of injection with saline or oestradiol $(50 \mu \mathrm{g})$. Days -11 to $0:$, mean of all ewes; Days 0 to 14: $\square--n$, Ewe 671 (see text); $-\rightarrow$ mean of Group 1, saline at 17.00 hours; ---0 , mean of Group 2 , oestradiol at 17.00 hours; $\nabla-\nabla$, mean of Group 3, saline at 05.00 hours; $\nabla---\nabla$, mean of Group 4, oestradiol at 05.00 hours. 
plant was intact and this ewe showed a drop in plasma progesterone $6 \mathrm{hr}$ after the implant had been removed. There was no evidence of FSH or LH peaks during the first $96 \mathrm{hr}$ after implant removal, and there were no enlarged follicles or corpora lutea.

\section{Plasma progesterone concentrations}

The concentrations in all the plasma samples taken while the implant was in situ and in some of the samples taken after implant removal are shown in Text-fig. 1. The mean plasma concentrations during the implant treatment period and $6 \mathrm{hr}$ after implant removal were similar for ewes in all groups and no significant differences were found during this time; thus the combined data from all nineteen ewes have been plotted. The plasma progesterone concentration (mean \pm S.D.) rose from a control value of $0.17<0.05 \mathrm{ng} / \mathrm{ml}$ to $0.55 \pm 0.19$ $\mathrm{ng} / \mathrm{ml}(P<0.001) 24 \mathrm{hr}$ after implant insertion. Although this concentration was maintained until Day -7, there was a progressive decline over the next 7 days, and, just before implant removal on Day 0 , the concentration had dropped to $0.21 \pm 0.05 \mathrm{ng} / \mathrm{ml}$, a significantly $(P<0.05)$ higher value than the mean before implant insertion. The mean plasma progesterone level dropped significantly to $0 \cdot 15 \pm 0.04 \mathrm{ng} / \mathrm{ml}(P<0.001) 6 \mathrm{hr}$ after removal of the implant.

In Text-fig. 1, the mean values for each group have been plotted separately for Days 1 to 14, and two phases can be recognized. During the first phase (Days 1 to 4), the mean plasma levels of the four groups were in the range 0.35 to $0.9 \mathrm{ng}$ progesterone $/ \mathrm{ml}$ plasma, and for each group the means were significantly higher $(P<0.001)$ than the mean observed $6 \mathrm{hr}$ after removal of the implant. The mean progesterone levels of ewes in Group 2 were higher than those of the other three groups: significantly greater than those of Group 4 on Day $1(P<0.05)$, of Group 1 on Day $2(P<0.005)$ and of all three groups on Day $3(P<0.05)$. The second phase began on Day 6 , as indicated by increasing progesterone levels, and individual results are shown in Table 1. By Day 9, all

Table 1. Day of the first observed rise in plasma progesterone concentration in ewes 6 to 14 days after removal of a progesterone implant (Day 0 ) and injection of saline (Groups 1 and 3 ) or oestradiol

(Groups 2 and 4)

\begin{tabular}{ccccc}
\hline & Group 1 & Group 2 & Group 3 & Group 4 \\
\hline & 7 & 7 & $6 \frac{1}{2}$ & $6 \frac{1}{2}$ \\
& 7 & 11 & $6 \frac{1}{2}$ & $6 \frac{1}{2}$ \\
& 9 & 14 & $6 \frac{1}{2}$ & $13 \frac{1}{2}$ \\
& 7 & 14 & $7 \frac{1}{2}$ & $10 \frac{1}{2}$ \\
Mean & $7 \cdot 4$ & $10 \cdot 6$ & $6 \cdot 7$ & $8 \cdot 7$ \\
\hline
\end{tabular}

See text for details of treatments.

nine ewes in Groups 1 and 3 (injected with saline) had elevated progesterone levels while only five out of the ten ewes in Groups 2 and 4 (injected with oestradiol) showed a similar rise. Although the mean plasma progesterone 
concentrations of Group 1 ewes were higher than those of Group 2, and those of Group 3 ewes tended to be higher than those of Group 4, these differences were not statistically significant because of the wide variations within groups.

\section{Plasma LH and FSH}

Plasma gonadotrophin levels 10 days after implant insertion did not differ significantly from the preimplantation values (Table 2). The higher mean plasma FSH concentrations in Group-4 ewes were not significantly different from those of ewes in the other groups $(P>0.05)$.

Table 2. Plasma concentrations of LH and FSH in anoestrous ewes before, and 10 days after, insertion of a progesterone implant

\begin{tabular}{lllllr}
\hline & \multicolumn{2}{c}{ Before implantation } & & \multicolumn{2}{c}{ After implantation } \\
\cline { 2 - 3 } \cline { 5 - 6 } & $L H$ & $F S H$ & & $L H$ & \multicolumn{1}{c}{$F S H$} \\
\hline Group 1 & $<1$ & $65 \cdot 0 \pm 37.9$ & & $<1$ & $77 \cdot 6 \pm 40 \cdot 4$ \\
Group 2 & $<1$ & $69.4 \pm 33.8$ & & $<1$ & $79.4 \pm 33.0$ \\
Group 3 & $<1$ & $64.0 \pm 22.9$ & & $<1$ & $69.8 \pm 31 \cdot 0$ \\
Group 4 & $<1$ & $116.0 \pm 56.9$ & & $<1$ & $126.4 \pm 51 \cdot 0$ \\
\hline
\end{tabular}

Values are expressed as mean \pm S.D. in $\mathrm{ng} / \mathrm{ml}$.

Data on plasma LH and FSH surges after implant removal are shown in Table 3. Seventeen ewes showed increases in plasma LH and FSH concentrations, with the maximum observed values occurring between 24 and $96 \mathrm{hr}$ after removal of the implant, and in all ewes peak $\mathrm{LH}$ and FSH values were coincident.

A comparison of the values for ewes in Groups 1 and 3, with those for ewes in Groups 2 and 4 showed that oestradiol injection $48 \mathrm{hr}$ after implant removal had little, if any, effect on the first peak with respect to maximum plasma gonadotrophin concentration or time of occurrence. The values for the ewes injected with saline (mean \pm S.D.) were $59 \cdot 1 \pm 36.5 \mathrm{ng} \mathrm{LH} / \mathrm{ml}, 188 \cdot 1 \pm 42 \cdot 2 \mathrm{ng}$ $\mathrm{FSH} / \mathrm{ml}$, and $49 \cdot 1 \pm 21 \cdot 0 \mathrm{hr}$; the corresponding means for the ewes injected with oestradiol were $76 \cdot 4 \pm 29 \cdot 2 \mathrm{ng} \mathrm{LH} / \mathrm{ml}, 233 \cdot 3 \pm 63 \mathrm{ng} \mathrm{FSH} / \mathrm{ml}$ and $41 \cdot 0 \pm 12 \cdot 4 \mathrm{hr}$, but the differences were not significant. A similar comparison of Group 1 and 2 with Groups 3 and 4 did not reveal any significant effect of time of implant removal on peak plasma gonadotrophin concentrations, although there was a tendency for the LH and FSH peaks to appear earlier in Groups 3 and 4.

Only one ewe (No. 570) in Groups 1 and 3 showed a second plasma gonadotrophin peak which was similar in magnitude to the first peak, but this response was not comparable with those of ewes in Groups 2 and 4 . Of the five ewes in Group 2, three showed a second slight increase in plasma $\mathrm{LH}$ and FSH following oestradiol injection. In two ewes, this second rise in plasma gonadotrophins was just detectable and was well separated from the first peak; in the third ewe (No. 615) the second peak occurred on the descending limb of the first LH and FSH surge and the value was probably an overestimate. In Group 4, the four ewes which showed a major response to progesterone implant removal also responded to oestradiol injection, and although the second 


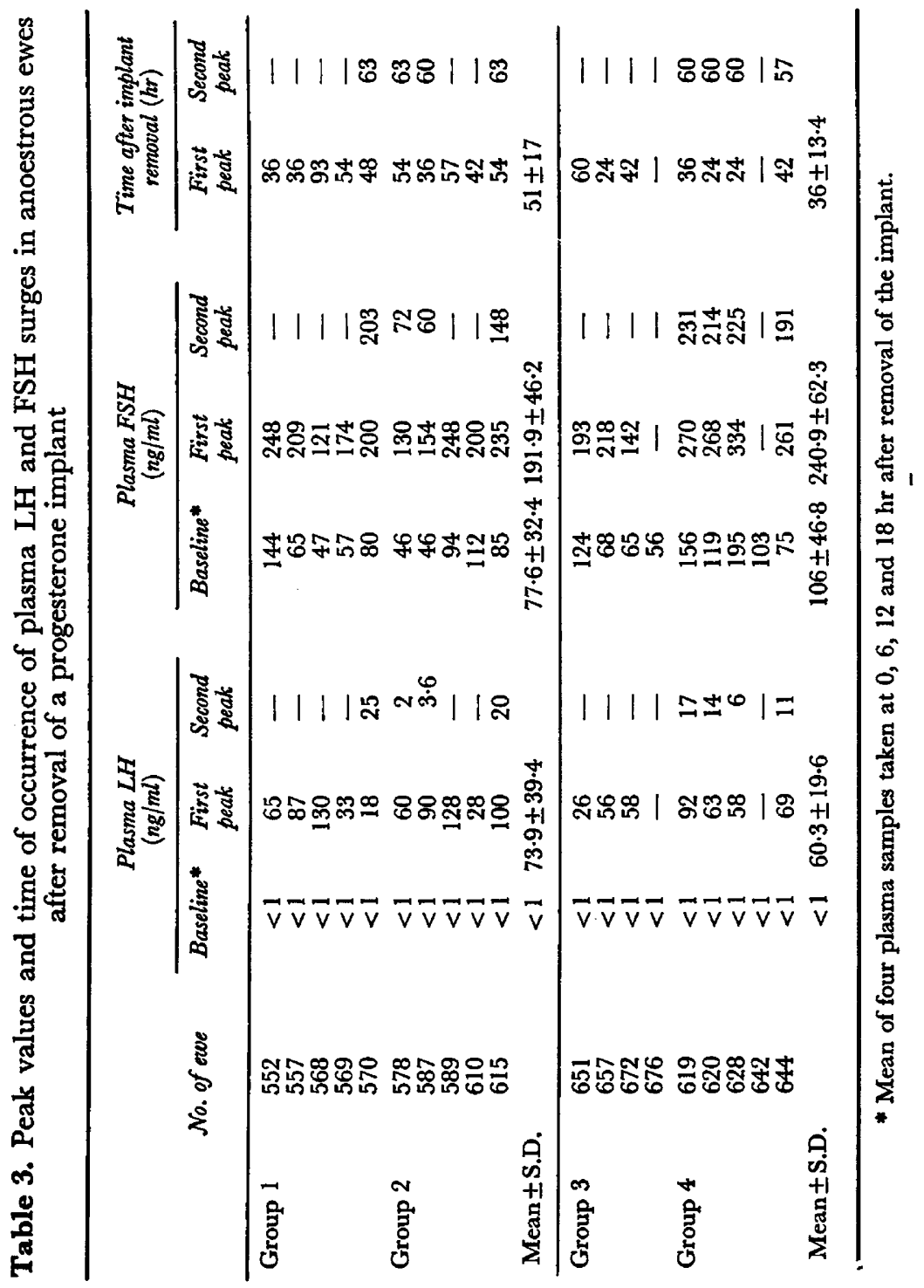


peak was considerably lower than the first peak, the increase in plasma LH and FSH was generally greater than the observed increases in Group 2 ewes. Ewe 642 did not show any rise in plasma gonadotrophins in response to either implant removal or oestradiol injection.

\section{Vulval changes and oestrous behaviour}

Text-figure 2 shows the total score per group for the period 0 to $39 \mathrm{hr}$ after the injection of oestradiol or saline. In the ewes injected with saline there was no detectable change in the vulval appearance of ewes in Group 3 and only a slight change in those of Group 1. Group-2 ewes showed intermediate oestrous changes 27 to $31 \mathrm{hr}$ after injection of oestradiol, i.e. during the 4th day after removal of the implant, and the vulvae of all ewes in Group 4 were typical of full oestrous development about $15 \mathrm{hr}$ after injection of oestradiol, i.e. during the 3rd day after removal of the implant.

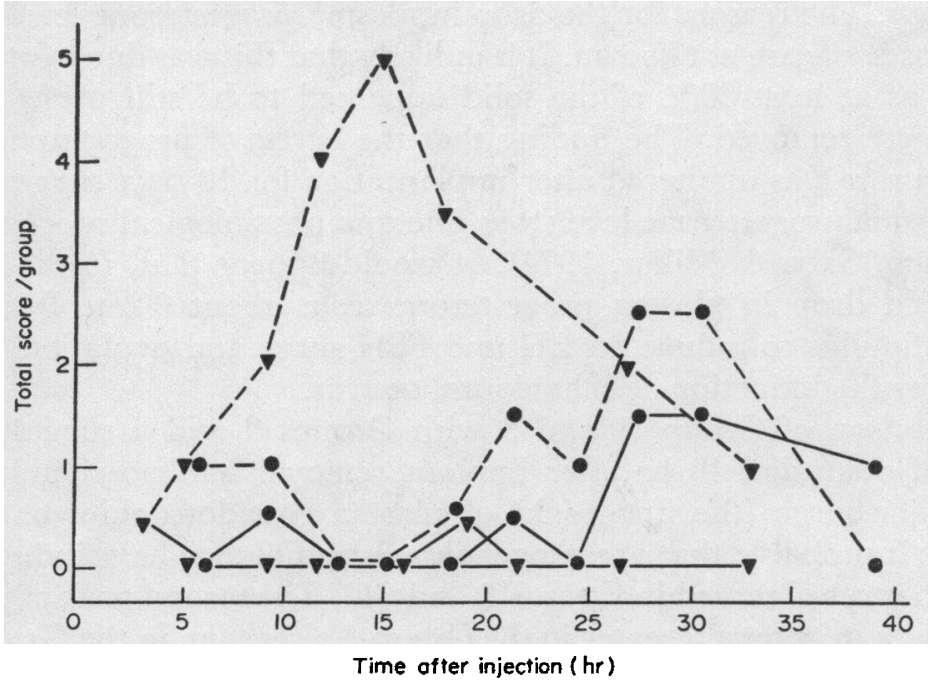

TEXT-FIG. 2. The vulval changes in anoestrous ewes after removal of a progesterone implant on Day 0 and injection of $2 \mathrm{ml}$ saline or $50 \mu \mathrm{g}$ oestradiol in $2 \mathrm{ml}$ saline on Day 2. The changes were scored as described in the text. - Group 1, saline at 17.00 hours; $\bullet---\bullet$, Group 2, oestradiol at 17.00 hours; $\nabla-\downarrow$, Group 3, saline at 05.00 hours; $\nabla---\nabla$, Group 4, oestradiol at 05.00 hours.

Behavioural oestrus was observed in only two ewes; Ewe 615 (Group 2) and Ewe 642 (Group 4) came into oestrus about $24 \mathrm{hr}$ and $18 \mathrm{hr}$, respectively, after injection of oestradiol.

\section{Ovulation}

Corpora lutea were present in all nineteen experimental ewes. The five control ewes had inactive ovaries with no large follicles or corpora lutea.

\section{DISCUSSION}

The results of the present experiment on anoestrous ewes with progesterone implants showed that removal of the implant was followed by a sequence of events which in some respects was similar to that seen in a normal cyclic ewe. In agreement with the observations of Mauer et al. (1972), removal of the implant 
induced a typical preovulatory peak of plasma LH and FSH within 24 to $96 \mathrm{hr}$ in seventeen of nineteen ewes, but only two of the ewes came into oestrus during this period compared to $67 \%$ in the study by Mauer et al. (1972). It is possible that breed difference and stage of anoestrus may account in some measure for this difference, but the type of implant used is probably of greater significance. Mauer et al. (1972) used implants of solid silicone rubber impregnated with $10 \%$ progesterone, and in the present study sealed silicone rubber tubing containing $100 \mathrm{mg}$ solid progesterone was used. After the insertion of solid silicone rubber implants impregnated with about $13 \%$ progesterone, plasma hormone levels rose to about $1.5 \mathrm{ng}$ progesterone/ml plasma within $24 \mathrm{hr}$ and dropped slightly after 10 days to $1 \cdot 1 \mathrm{ng}$ progesterone/ml (Cunningham, Saba \& Millar, 1975); these concentrations are higher than those in the present study in which the highest observed mean plasma progesterone concentration was $0.52 \mathrm{ng} / \mathrm{ml}$ dropping to a mean concentration only slightly greater than control values after 10 days. The reasons for the drop in plasma progesterone levels while the implant was in situ are not known. It is unlikely that this was due to progesterone depletion, as at least $80 \%$ of the solid appeared to be still present after the implants were removed. The finding that the egress of progesterone from the implants in vitro was unaltered after implantation for 10 days suggests that the drop in plasma progesterone levels was due to a physiological process (Symons, Cunningham, Saba \& Millar, 1974). It would appear that, in the anoestrous ewe, a rapid drop in plasma progesterone from about 0.2 to $0.15 \mathrm{ng} / \mathrm{ml}$ is sufficient stimulus to induce an LH and FSH surge and ovulation, but is not adequate for the induction of behavioural oestrus.

A comparison of Groups 1 and 3 with Groups 2 and 4 suggests that the injection of oestradiol $48 \mathrm{hr}$ after implant removal had no significant effect on the major surge (the first peak) of plasma gonadotrophins or ovulation, although it is probable that the exogenous oestradiol may have induced the behavioural oestrus observed in Ewes 615 and 642. The second peak of plasma LH and FSH was in general greater in the Group-4 ewes than in the Group-2 ewes.

The responses of ewes in Groups 2 and 4 to exogenous oestradiol were much less than those reported in other studies in which injection of 25 to $1600 \mu \mathrm{g}$ oestradiol into anoestrous ewes resulted in large surges of plasma LH within $24 \mathrm{hr}$ (Goding \& co-authors, 1969; Radford, Wallace \& Wheatley, 1971; Symons, Cunningham \& Saba, 1973a, b). The reasons for this are not clear. Cumming, Brown, Blockey \& Goding (1971) have suggested that progesterone infusion into ewes may suppress the LH surge caused by oestradiol, and it is possible that, in the present study, the slightly elevated plasma progesterone levels at the time of oestrogen injection (Day 2) may have suppressed or reduced the response to oestradiol. It is also possible that the stimulus for a plasma gonadotrophin surge initiated by implant removal may have resulted in a block to oestradiol action. It has been shown that the LH surge in anoestrous ewes injected with oestradiol was depressed if the animals had been injected with either LH-RH or oestradiol $24 \mathrm{hr}$ previously (Symons et al., 1973a). A similar block to oestradiol action was observed in cyclic ewes $24 \mathrm{hr}$ after oestrus (Symons et al., 1973b). Although the response of ewes in Groups 2 and 4 to the injection of oestradiol was apparently diminished, the data suggest that the suppression of the plasma LH and FSH surge was greater in Group 2 than in 
Group 4 and indicate that the time of implant removal can have some effect on the response of the animal. This possibility is supported from the timing of the first plasma gonadotrophin surge; this surge occurred at a mean time of $51 \mathrm{hr}$ in Groups 1 and 2 and $36 \mathrm{hr}$ in Groups 3 and 4 after implant removal, i.e. the greater response to oestradiol injection found in Group 4 compared to Group 2 could be due to the earlier occurrence of the first plasma gonadotrophin surge in Group 4. It is unlikely that the time of oestradiol injection was responsible for this difference between Groups 2 and 4 as Jackson \& Thurmon (1974) have shown that the oestrogen-induced release of $\mathrm{LH}$ in anoestrous ewes is unaffected by the time of treatment.

The causes for the increase in plasma progesterone levels found during Days 1 to 4 after removal of the implant are not known. It seems unlikely to be due either to residual progesterone from the implant, as the progesterone values had dropped to control levels $6 \mathrm{hr}$ after implant removal, or to corpus luteum formation. Wheatley \& Radford (1969) showed that ovulation occurred about $24 \mathrm{hr}$ after the LH surge, so that in the present experiment the earliest ovulation would not have occurred until at least 2 days after removal of the implant.

The increase in plasma progesterone concentration that occurred in Group-2 ewes on Day 3, $24 \mathrm{hr}$ after the injection of $50 \mu \mathrm{g}$ oestradiol, may represent a change in progesterone metabolism in response to an oestrogen stimulus, although the fact that Group-4 ewes did not respond similarly argues against this. The time of administration of oestradiol ( 05.00 or 17.00 hours), however, may have modified the response to the hormone, since several reports have indicated that the action of hormones may be modified according to the time of treatment (McCormack \& Meyer, 1963; Ying \& Greep, 1971; Jackson, 1972, 1973). The better vulval responses observed in the Group-4 ewes in the present studies are a further indication of the effect of time of hormone administration, although altered progesterone metabolism may also have been involved.

The progressive increase in plasma progesterone concentrations occurring from Day 6 after removal of the implant and reaching maximum observed values by Days 13 to 14 was probably due to the presence of active corpora lutea.

The results from Ewes 676 (Group 3) and 642 (Group 4) were unusual and interesting in that ovulation occurred, apparently without a previous surge in plasma gonadotrophins. Since blood samples were taken at 6-hr intervals for the first $48 \mathrm{hr}$ after implant removal and at 3-hr intervals for the next $48 \mathrm{hr}$, the duration of a gonadotrophin surge occurring during this period would have been abnormally brief. The possibility that the surge in plasma gonadotrophins in these two ewes occurred after $96 \mathrm{hr}$ cannot be excluded, although this is a considerably longer interval than those reported by Mauer et al. (1972), and those generally found in this study.

Two interesting features of these results are the sensitivity of the ewe to the rapid but slight drop in circulating plasma progesterone levels following implant removal, and the dissociation of hormonal changes leading to ovulation from oestrous behaviour. It is not clear from the present experiment whether the changes observed after implant removal were due solely to the decrease in plasma progesterone or to a combination of this decrease and the initial dose of $500 \mu \mathrm{g}$ oestradiol given at the time of implant insertion. There was some evi- 
dence that a plasma gonadotrophin surge occurred in response to the initial $500 \mu \mathrm{g}$ dose of oestradiol, as thirteen of the ewes had plasma LH levels of 1.2 to $7.8 \mathrm{ng} / \mathrm{ml}$ on Day -9 that were significantly higher than the baseline value of $<1 \mathrm{ng} / \mathrm{ml}$. Further studies would be required to assess the effect of such an LH surge on the response of ewes to progesterone implants.

The sealed Silastic tubing implants cannot be used to induce synchronized oestrus as the first ovulation after removal of the implant is rarely associated with oestrous behaviour. Further studies are needed to determine if this first induced 'silent' oestrous cycle is followed by a cycle with full oestrous behaviour.

\section{AGKNOWLEDGMENTS}

We should like to thank Mr J. J. P. Hattersley, Mr R. Jackson and Miss E. M. Dawson for valuable technical assistance.

\section{REFERENGES}

Gumming, I. A., Brown, J. M., Blockey, M. A. De B. \& Goding, J. R. (1971) Regulation of the oestrous cycle in the ewe. F. Reprod. Fert. 24, 148-149.

Cunningham, N. F. \& Hebert, G. N. (1973) A solid-phase radioimmunoassay for ovine folliclestimulating hormone. F. Endocr. 58, 239-249.

Gunningham, N. F., SABA, N. \& Millar, P.G. (1975) Release of progesterone from silicone rubber implants in vitro, and the effects of the implants on plasma progesterone levels in sheep. 7 . Reprod. Fert. 43, 555-558.

Dziuk, P. J. \& Cook, B. (1966) Passage of steroids through silicone rubber. Endocrinology, 78, 208-211.

Falkenburg, J. A., Hulet, G. V. \& Kaltenbach, C. C. (1971) Effects of hormone combinations on estrus, ovulation and fertility of ewes. J. Anim. Sci. 32, 1206-1211.

Goding, J. R., Gatt, K. J., Brown, J. M., Kalrenbach, G. G., Gumming, I. A. \& Mole, B. J. (1969) Radioimmunoassay for ovine luteinizing hormone. Secretion of luteinizing hormone during estrus and following estrogen administration in sheep. Endocrinology, 85, 133-142.

JACKson, G. L. (1972) Blockage of progesterone-induced release of luteinizing hormone by actinomycin $\mathrm{D}$ or reserpine and comparison of effects of progesterone and estrogen on release of luteinizing hormone in the rat. Endocrinology, 90, 874-879.

JACKson, G. L. (1973) Effect of progesterone on release of luteinizing hormone in gonadectomized adult and immature rats. Biol. Reprod. 8, 58-61.

JACKson, G. L. \& ThuRMon, J. G. (1974) Absence of a critical period in estrogen-induced release of LH in the anestrous ewe. Endocrinology, 94, 918-920.

MCCormack, G. E. \& MEXER, R. K. (1963) Ovulation induced by progesterone in immature rats pretreated with pregnant mare serum gonadotrophin. Gen. $\mathcal{E}$ compar. Endocr. 3, 300-307.

Mauer, R. E., Revenal, P., Johnson, E. S., Moyer, R. H., Hirata, A. \& White, W. F. (1972) Levels of luteinizing hormone in sera of ewes near the time of estrus as determined by radioimmunoassay. F. Anim. Sci. 34, 88-92.

RAdFord, H. M., WALlace, A. L. \& WheATley, I.S. (1971) Steroid-induced gonadotrophin release in the ewe. 7. Reprod. Fert. 24, 147-148.

Symons, A. M. (1973) Levels of oestrogen and progesterone in the plasma of the cow during the last month of pregnancy. 7 . Endocr. 56, 327-328.

Symons, A. M., Gunningham, N. F. \& Saba, N. (1973a) Preliminary observations on the effect of luteinizing hormone-releasing factor and oestradiol-17 $\beta$ on plasma gonadotrophin levels in the anoestrous ewe. 7 . Endocr. 58, xii-xiii.

Symons, A. M., Gunningham, N. F. \& SABA, N. (1973b) Oestrogen-induced LH surges in the anoestrous and cyclic ewe. 7 . Reprod. Fert. 35, 569-571.

Symons, A. M., Cunningham, N. F. \& Saba, N. (1974) The gonadotrophin hormone response of anoestrous and cyclic ewes to synthetic luteinizing hormone-releasing hormone. F. Reprod. Fert. $39,11-21$.

Symons, A. M., Gunningham, N. F., SAba, N. \& Millar, P. G. (1974) Girculating progesterone levels in anoestrous sheep with silicone rubber progesterone implants. F. Reprod. Fert. 41, 475-477.

WheATLEY, I. S. \& RADFORD, H. M. (1969) Luteinizing hormone secretion during the oestrous cycle of the ewe as determined by radioimmunoassay. F. Reprod. Fert. 19, 211-216.

YING, S. Y. \& GREEP, R. O. (1971) Effect of age of rat and dose of a single injection of estradiol benzoate (EB) on ovulation and the facilitation of ovulation by progesterone. Endocrinology, 89, 785790. 